\begin{tabular}{c|l|l|l}
$\begin{array}{c}\text { Case Reports in } \\
\text { Oncology }\end{array}$ & $\begin{array}{l}\text { Case Rep Oncol 2010;3:354-361 } \\
\text { DOI: 10.1159/000321281 }\end{array}$ & $\begin{array}{l}\text { Published online: } \\
\text { October 9, 2010 }\end{array}$ & $\begin{array}{l}\text { O 2010 S. Karger AG, Basel } \\
\text { ISSN 1662-6575 } \\
\text { www.karger.com/cro }\end{array}$ \\
\hline
\end{tabular}

This is an Open Access article licensed under the terms of the Creative Commons AttributionNonCommercial-NoDerivs 3.0 License (www.karger.com/OA-license), applicable to the online version of the article only. Distribution for non-commercial purposes only.

\title{
Varied Presentation of Schwannoma - A Case Study
}

\author{
Ruquaya Mir Vikram Pratap Singh $^{a}$ Sumaid Kaul

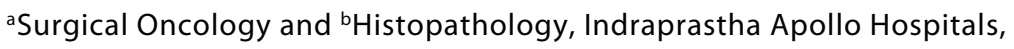 \\ New Delhi, India
}

\section{Key Words}

Schwannoma Varied presentation $\cdot$ Computed tomography $\cdot$ MRI $\cdot$ Histopathology

\begin{abstract}
Schwannomas can occur anywhere in the body with unusual presentation. They are difficult to diagnose preoperatively. Fine needle aspiration biopsy does not appear to provide an accurate preoperative diagnosis. Complete excision of the mass should be the goal of surgical excision.
\end{abstract}

\section{Case Reports}

Case 1

A 23-year-old nulliparous woman presented with pain in the left lower abdomen, leg pain, incomplete evacuation of the bladder and difficult passage of stools for 2 months. On examination, a large firm mass of 14-16 weeks' size filling the vagina was found. There was no neurological deficit. Ultrasound of the pelvis showed a large complex left parauterine mass (cystadenoma/ cystadenocarcinoma). Contrast-enhanced computed tomography of the abdomen showed a $12.4 \times 11.5$ $\times 15 \mathrm{~cm}$ mass in the pelvis, highly suggestive of a malignant ovarian mass. Intravenous urogram showed a displaced left ureter (fig. 1). CA 125 was $10.5 \mathrm{U} / \mathrm{ml}$. A benign cystic lesion was reported by ultrasound-guided fine needle aspiration biopsy. On laparotomy, a large $14 \times 12 \times 10 \mathrm{~cm}$ multiloculated cyst arising from the left broad ligament was seen with the left ovary and fallopian tube stretched and densely adherent. The left ureter was pushed to the right side. The tumor was densely adherent to the urinary bladder, rectum and left iliac vessels. Left salpingo-oophorectomy with excision of the entire cyst was done after safeguarding the left ureter, rectum and urinary bladder. Histopathology showed a well-encapsulated variably cellular neoplasm composed of cells arranged in sheets, whorls and fascicles. Areas of hypercellularity (Antoni type A) showed nuclear palisading, forming verocay bodies. Hypocellular areas (Antoni type B) showed edema and cystic degeneration. The tumor cells were positive for S-100, vimentin and negative for SMA and CD34.

\section{Case 2}

A 50-year-old healthy man presented with a history of difficulty in walking for 2.5 years. Lately, he was having difficulties in balancing the body while walking, associated with progressive weakness of all 4 limbs, urgency of micturition and constipation. MRI of the cervical spine showed a large extramedullary 
solid mass in the right epidural space with paravertebral extension located at the C7-D1 level (fig. 2a, b). There was widening of the intervertebral neural foramina with distortion and compression of the spinal cord. The patient underwent cervical laminectomy with excision of the intra-spinal and extra-foraminal extension of the tumor. Histopathology reported spindle-shaped cells with hyper- and hypocellular areas, and nuclear palisading forming verocay bodies. Tumor cells were positive for S-100.

\section{Case 3}

A 22-year-old male patient who was otherwise asymptomatic and a non-smoker was informed about a mass in the left chest on routine health check-up approximately 4 years ago. Presently, the patient had a dull aching pain in the left lower chest and occasional vomiting. He did not have any history of cough, fever, hemoptysis or weight loss. He was examined at our institution. Chest X-ray showed a left paracardiac mass. MRI of the chest showed a large lobulated lesion in the left hemithorax with extension into the posterior mediastinum abutting the left diaphragm (fig. 3a, b). Ultrasound of the abdomen was normal. CT-guided Tru-cut biopsy was suggestive of a mesenchymal neoplasm of nerve sheath origin. The patient underwent complete excision of the tumor by left posterolateral thoracotomy. Histopathology showed a mesenchymal neoplasm of nerve sheath origin with tumor cells forming palisades. Verocay bodies were identified and sprinkling of lymphonuclear cells was seen throughout. Tumor cells were strongly positive for S-100 protein.

\section{Case 4}

A 27-year-old male patient, who was married and a non-smoker, presented with a history of prepuceal swelling of 2 years duration. There was no history of difficulty in urination or sexually transmitted disease. Clinically, there was a soft $3 \times 3 \mathrm{~cm}$ lesion involving the prepuce on the ventral aspect of the penis. Excision was done and histopathology showed a well-defined tumor within the subcutis comprising cells arranged in fascicles and prominent palisades. Verocay bodies were present, and hyalinized cellular areas and foci of old hemorrhage were seen. Tumor cells were strongly positive for S-100 protein (fig. 4, fig. 5, fig. 6, fig. 7).

\section{Case 5}

A 69-year-old otherwise healthy woman presented with a history of recurrent diarrhea for the last 8 years. The patient also had a history of giddiness, postural hypotension, palpitation and syncopal attacks. She had no history of episodic headache. The findings of repeated colonoscopic examinations were normal. Contrast-enhanced computed tomography of the abdomen showed an $8 \times 5 \times 4.6 \mathrm{~cm}$ well-defined lesion in the left paravertebral region at the level of the L3-L5 vertebra. MRI showed a retroperitoneal mass at $\mathrm{L} 4-\mathrm{S} 1$ level medial to the left psoas muscle with no intraspinal extension. Her 24-hour urinary dopamine, epinephrine and normetanephrine were raised. The patient underwent excision of the retroperitoneal tumor with provisional diagnosis of functional paraganglioma. Histopathology showed a well-encapsulated tumor with spindle-shaped cells. Nuclei were elongated and vesicular. Palisading of tumor cells was seen. Few verocay bodies were present along with hyalinized blood cells. Tumor cells were strongly positive for S-100 protein.

\section{Case 6}

A 21-year-old woman had presented with a right-sided retroperitoneal mass which was excised. She noticed a progressively enlarging lump at the same site with pain in the right hip joint radiating to the right leg. She had multiple nevi and multiple nodular lesions all over her body. MRI showed a lobulated, multiseptated soft-tissue mass in the right iliac fossa involving the iliopsoas muscle, subcutaneous fat and the abdominal wall muscle. The tumor had an extension into the gluteus maximus and medius muscle. There was widening of the sacral canal and effacement of fat around the right 2 nd and 3rd sacral foramina. On laparotomy, a large mass densely adherent to the right iliopsoas muscle with entrapment of the femoral nerve was found. Wide excision of the tumor was done with sacrifice of the right femoral nerve. Biopsy of the nodular skin lesion was also done at the same time. Histopathology of 


\begin{tabular}{r|l|l|l}
$\begin{array}{c}\text { Case Reports in } \\
\text { Oncology }\end{array}$ & $\begin{array}{l}\text { Case Rep Oncol 2010;3:354-361 } \\
\text { DOI: 10.1159/000321281 }\end{array}$ & $\begin{array}{l}\text { Published online: } \\
\text { October 9, 2010 }\end{array}$ & $\begin{array}{l}\text { O 2010 S. Karger AG, Basel } \\
\text { ISSN 1662-6575 } \\
\text { www.karger.com/cro }\end{array}$ \\
\hline
\end{tabular}

the main lesion showed a malignant schwannoma and the skin lesions were neurofibromas. It was a case of Von Recklinghausen's disease with malignant schwannoma.

\section{Discussion}

Schwannomas (neurilemmomas) are a subclass of soft-tissue neoplasms that include both malignant and benign schwannomas. Schwannomas may occur in any organ or nerve trunk, with the exception of cranial nerves I and II, which lack Schwann cells. Schwannomas are associated with Von Recklinghausen's disease in 5-18\% of cases, and patients generally present between the ages of 20 and 50 years, with only $5 \%$ having onset in childhood or adolescence [1].

In the absence of Von Recklinghausen's disease, these masses rarely occur in the retroperitoneum, comprising 3\% of all schwannomas (malignant and benign combined) [2]. Schwannomas are benign, slow-growing encapsulated tumors of nerve sheath origin found most commonly in the extremities and head and neck region. Microscopically, lesions display a biphasic pattern with areas of highly ordered cellularity (Antoni type A) and other less cellular areas where a copious myxoid matrix predominates (Antoni type B). Cyst formation, calcification, hemorrhage and hyalinization may be revealed on histologic examination [3]. Intense immunostaining for S-100 protein suggests their neural origin.

On gross appearance, schwannomas are usually solitary, well-circumscribed, firm, smooth-surfaced tumors. Malignant degeneration is extremely rare. Malignant peripheral schwannomas or malignant peripheral nerve sheath tumors act as high-grade sarcomas with a high likelihood of producing local recurrence and distant metastasis as in one of our patients (case 6).

Symptoms produced are due to organ displacement or pressure effects on surrounding structures. In our series, two patients had neurological symptoms due to an intraspinal component in one patient and entrapment of the femoral nerve in a patient with Von Recklinghausen's disease (case 2 and case 6, respectively).

Large tumors tend to be highly vascular [4], with central hemorrhage, cystic degeneration and calcification as in one of our patients (case 1). Tumor size does not appear to be associated with the degree of aggressiveness or malignant potential [5]. Large masses tend to displace retroperitoneal structures like the ureter, uterus and bladder as in one of our patients (case 1).

Ancient schwannomas may tend to be mistaken for ovarian disease clinically because the patients are usually asymptomatic and ultrasonography or other imaging modalities reveal totally cystic or solid and cystic masses. On ultrasound, large retroperitoneal neurilemmomas appear as heterogeneous, hyperechoic lesions with a prominent cystic component [9].

Kim et al. [6] described CT and MR findings of retroperitoneal schwannomas as welldefined round masses with multiple well-demarcated cystic areas of low to intermediate signal intensity on T1-weighted images and high signal intensity on T2-weighted images. The relatively high signal intensity on T2-weighted images is caused by a predominance of hypocellular Antoni type A tissue. A marginal crescent-shaped solid component is a characteristic finding of ancient schwannoma due to its secondary degenerative changes 


\begin{tabular}{r|l|l|l}
$\begin{array}{c}\text { Case Reports in } \\
\text { Oncology }\end{array}$ & $\begin{array}{l}\text { Case Rep Oncol 2010;3:354-361 } \\
\text { DOI: 10.1159/000321281 }\end{array}$ & $\begin{array}{l}\text { Published online: } \\
\text { October 9, 2010 }\end{array}$ & $\begin{array}{l}\text { O 2010 S. Karger AG, Basel } \\
\text { ISSN 1662-6575 } \\
\text { www.karger.com/cro }\end{array}$ \\
\hline
\end{tabular}

[6]. Fine needle aspiration may be helpful only if the sample has enough Schwann cells to visualize microscopically [7]. CT-guided biopsy is usually unreliable because of cellular pleomorphism [8].

Management of neural sheath tumors is complete excision, which may include sacrifice of adjacent tissue or viscera to attain negative tissue margin [9]. Others believe that because this is a benign mass, simple enucleation is sufficient [10]. In our series, all patients underwent complete excision. None of our patients had any recurrence except for a patient with a malignant nerve sheath tumor with a background of neuromatosis (case 6). Complete surgical resection with partial or complete resection of the viscera so as to attain negative margin is recommended [8].

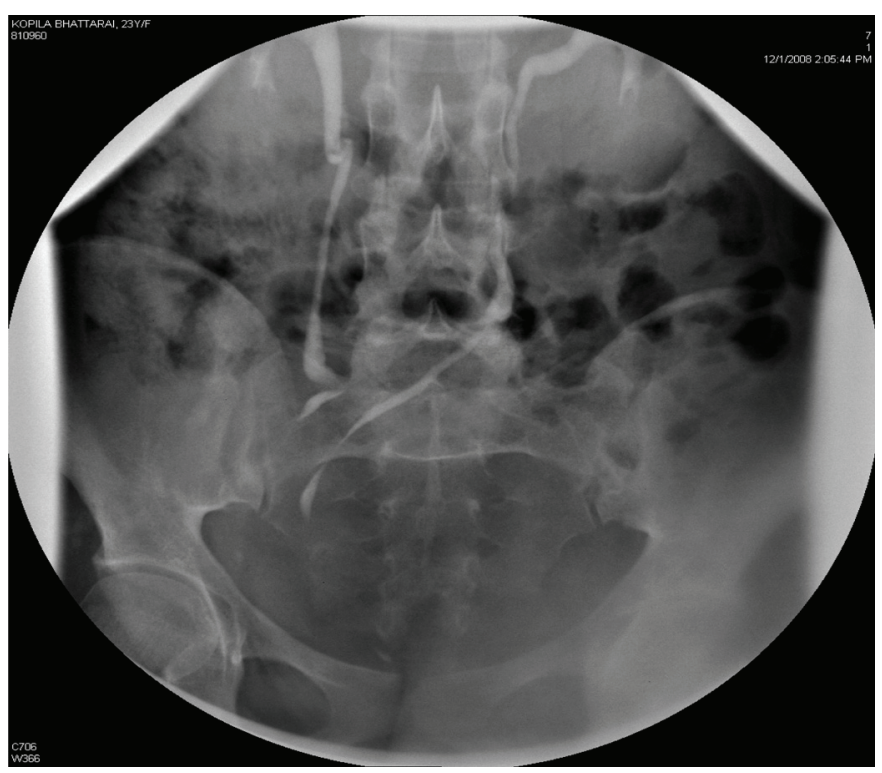

Fig. 1. Intravenous pyelography showing soft tissue in the pelvis on the left side with displacement of the left lower ureter to the contralateral side. No ureter dilatation is seen, however. The right ureter appears normal. 


\begin{tabular}{c|l|l|l}
$\begin{array}{c}\text { Case Reports in } \\
\text { Oncology }\end{array}$ & $\begin{array}{l}\text { Case Rep Oncol 2010;3:354-361 } \\
\text { DOI: 10.1159/000321281 }\end{array}$ & $\begin{array}{l}\text { Published online: } \\
\text { October 9, 2010 }\end{array}$ & $\begin{array}{l}\text { O 2010 S. Karger AG, Basel } \\
\text { ISSN 1662-6575 } \\
\text { www.karger.com/cro }\end{array}$ \\
\hline
\end{tabular}

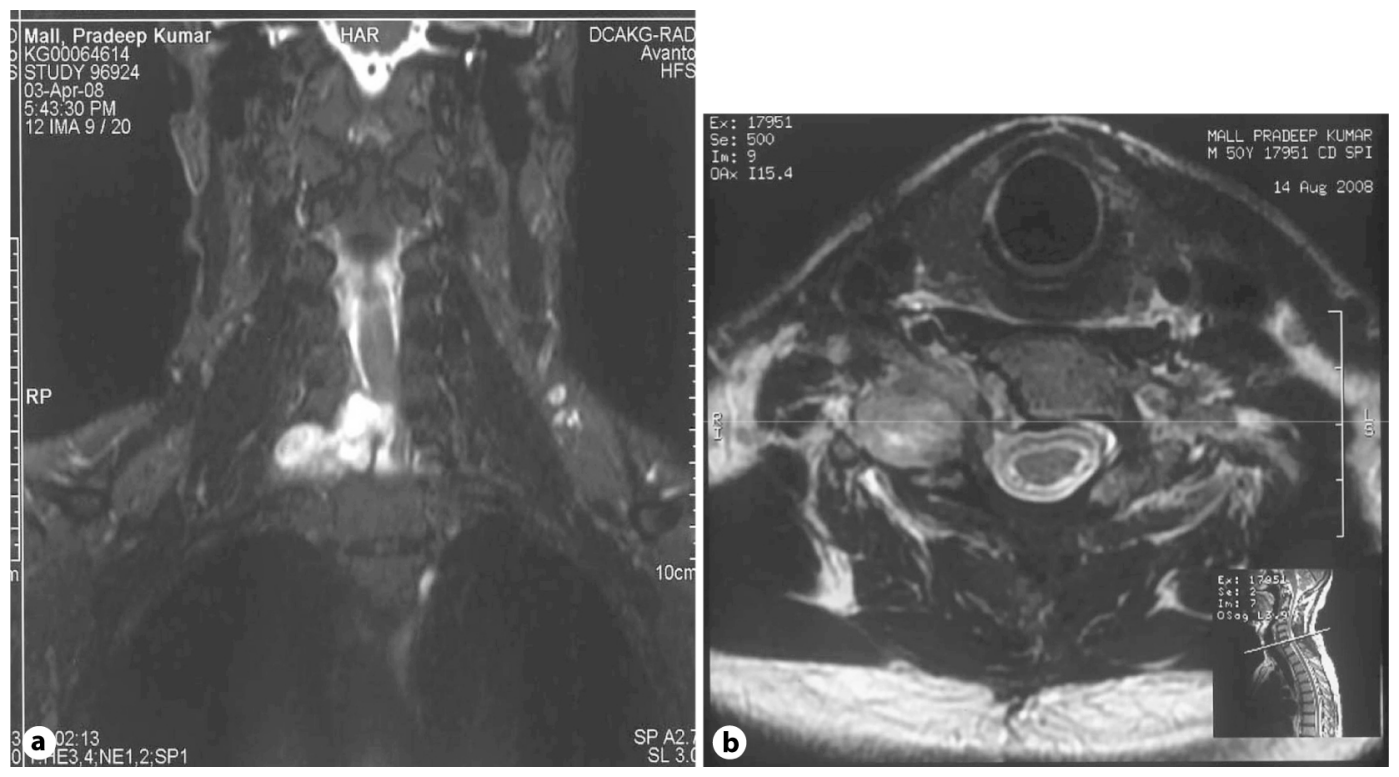

Fig. 2. a, b A lobulated dumb bell-shaped soft-tissue signal intensity mass is seen in the right paravertebral region opposite the C7-D1 level with an extension through the C7-D1 neural foramen. The cervical cord is seen displaced towards the left side.

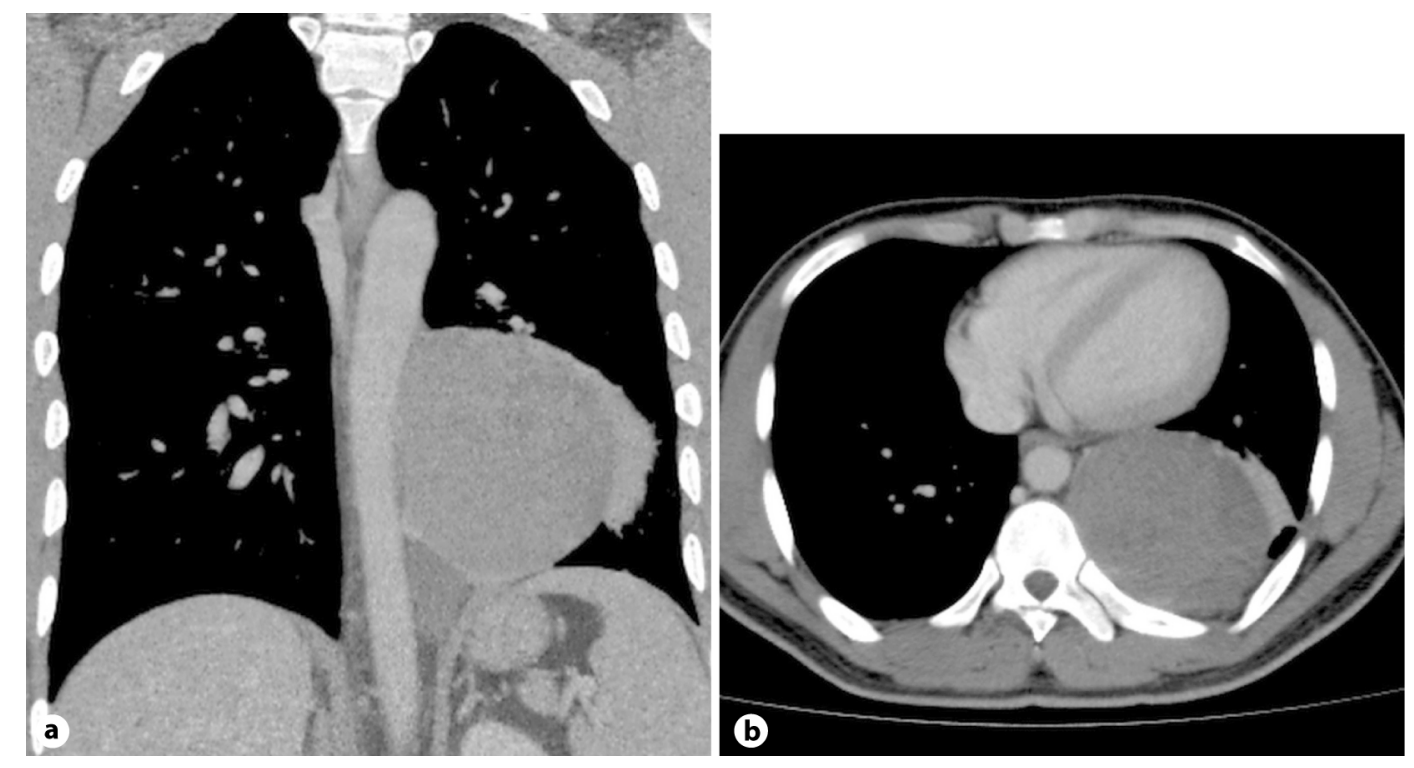

Fig. 3. a, b Axial and coronal images showing a lobulated soft-tissue mass in the paravertebral region. No intradural extension is seen. 


\begin{tabular}{c|l|l|l}
$\begin{array}{c}\text { Case Reports in } \\
\text { Oncology }\end{array}$ & $\begin{array}{l}\text { Case Rep Oncol 2010;3:354-361 } \\
\text { DOI: 10.1159/000321281 }\end{array}$ & $\begin{array}{l}\text { Published online: } \\
\text { October 9, 2010 }\end{array}$ & $\begin{array}{l}\text { O 2010 S. Karger AG, Basel } \\
\text { ISSN 1662-6575 } \\
\text { www.karger.com/cro }\end{array}$ \\
\hline
\end{tabular}

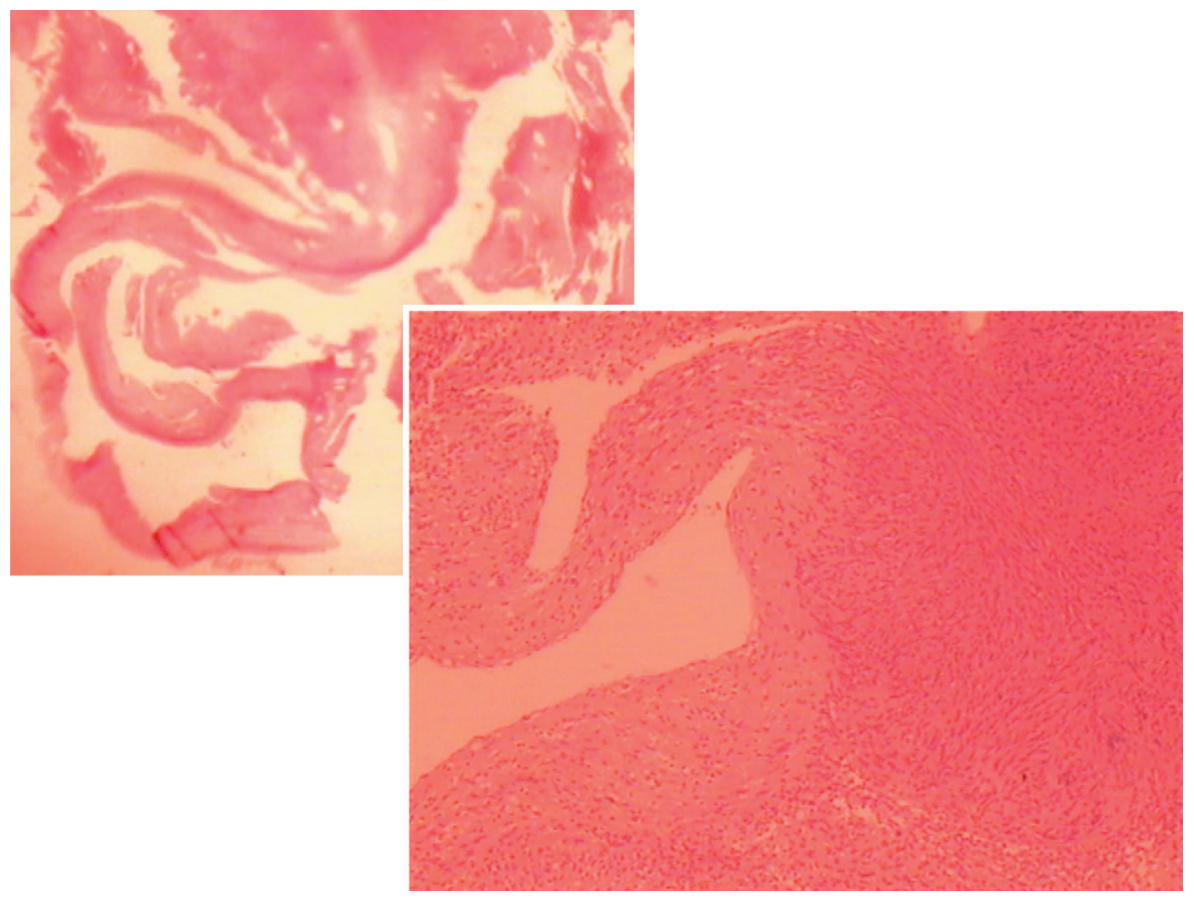

Fig. 4. Spindly cells in sheets and interlacing fascicles. HE. $\times 10$.

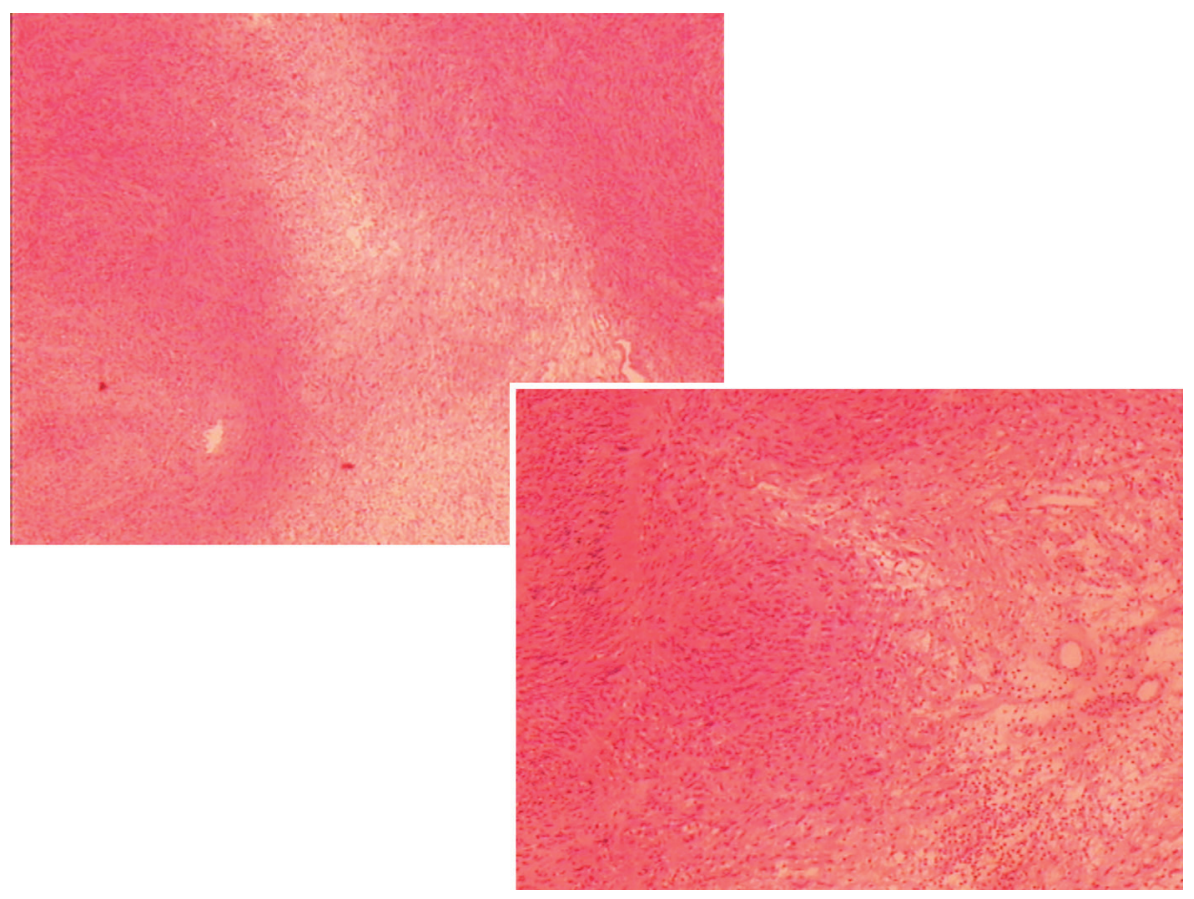

Fig. 5. Cellular areas alternating with poorly cellular areas; monomorphic, finely chromatic nuclei. HE. $\times 20$. 


\begin{tabular}{c|l|l|l}
$\begin{array}{c}\text { Case Reports in } \\
\text { Oncology }\end{array}$ & $\begin{array}{l}\text { Case Rep Oncol 2010;3:354-361 } \\
\text { DOI: 10.1159/000321281 }\end{array}$ & $\begin{array}{l}\text { Published online: } \\
\text { October 9, 2010 }\end{array}$ & $\begin{array}{l}\text { O 2010 S. Karger AG, Basel } \\
\text { ISS 1662-6575 } \\
\text { www.karger.com/cro }\end{array}$ \\
\hline
\end{tabular}
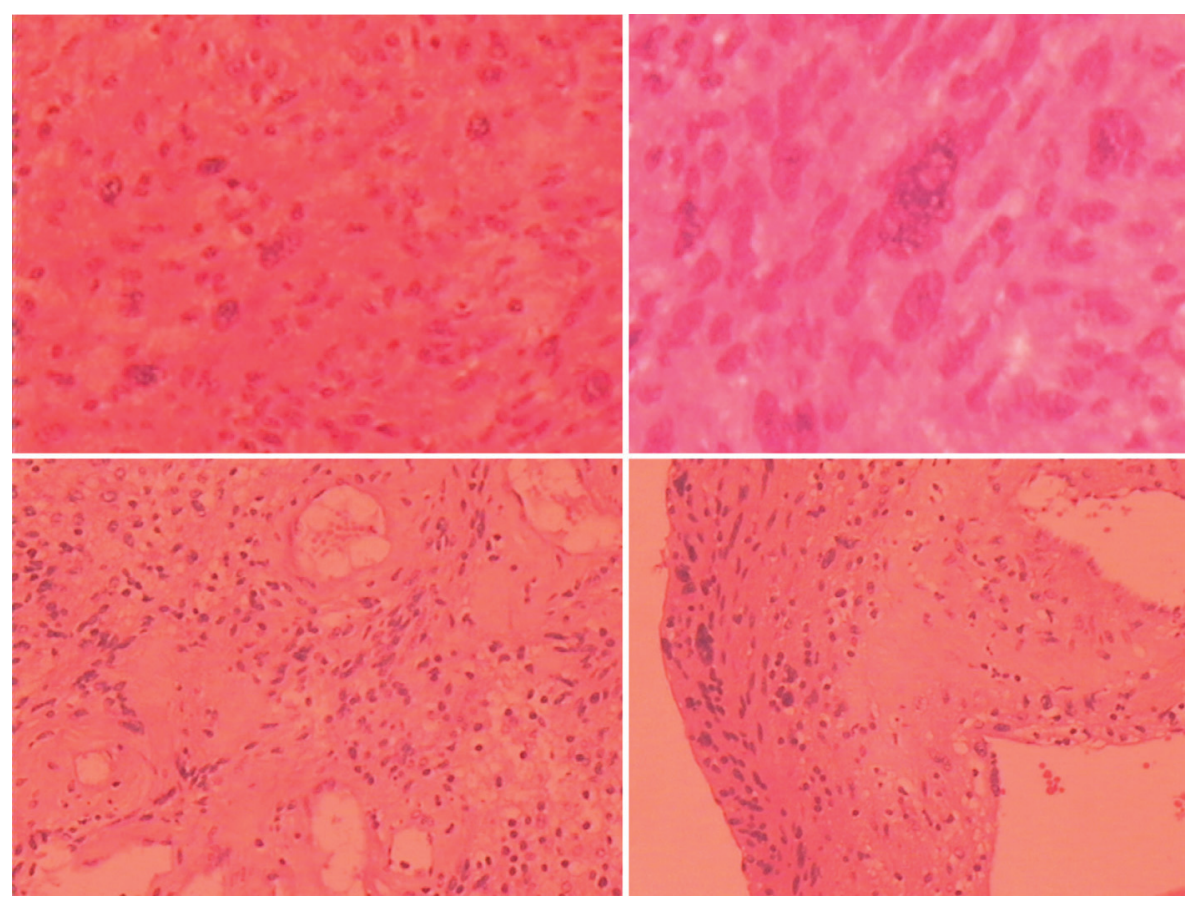

Fig. 6. Poorly cellular areas, with microcystic change. HE. $\times 10$.
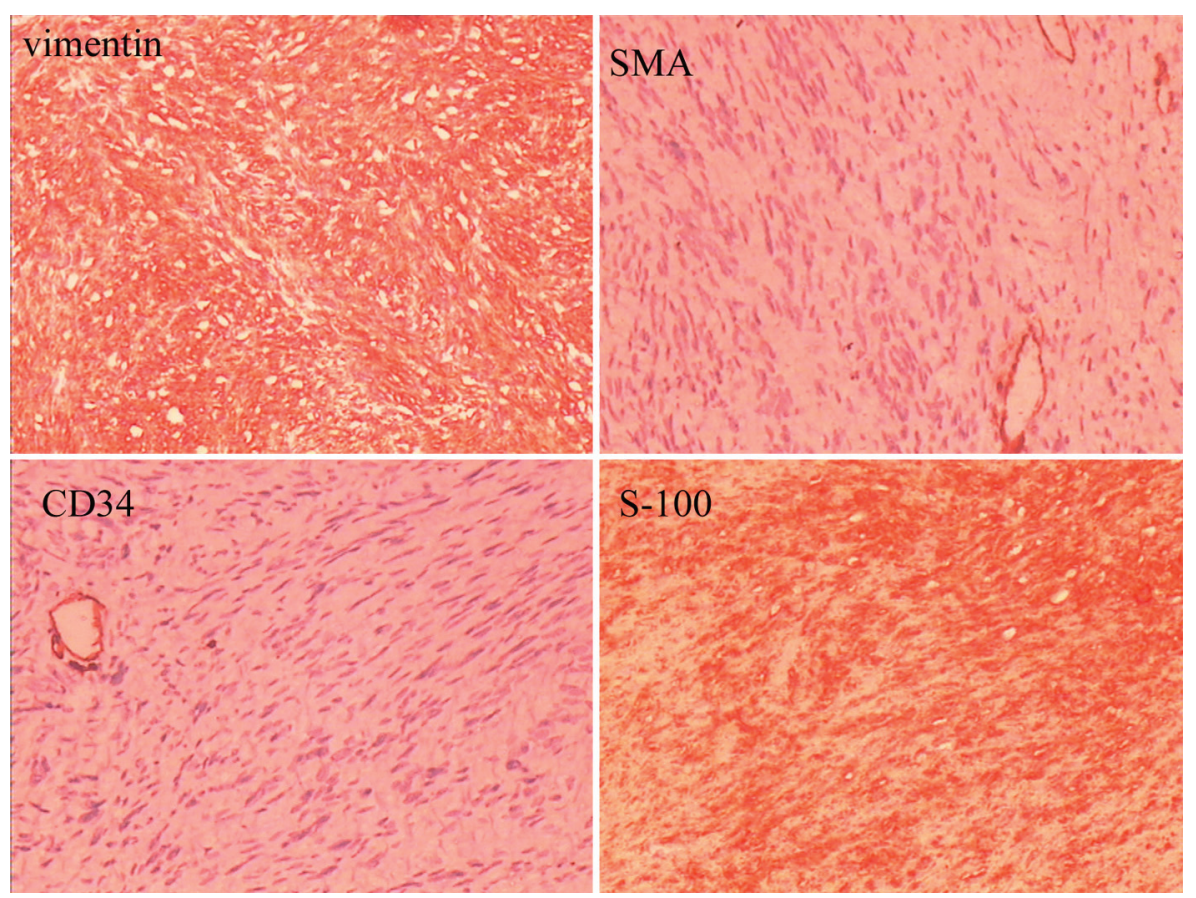

Fig. 7. Immunohistochemistry: tumor cells are positive for vimentin and S-100 protein, confirming their mesenchymal and nerve sheath origin, respectively. They are negative for CD34 and SMA. $\times 10$. 


\section{References}

1 Antiheimo J, Sankila R, Carpen O, et al: Population-based analysis of sporadic and type 2 neurofibromatosisassociated meningiomas and schwannomas. Neurology 2000;54:71-76.

2 Gubbay AD, Moschilla G, Gray BN, et al: Retroperitoneal schwannoma: a case series and review. Aust NZJ Surg 1995;65:197-200.

3 Enzinger FM, Weiss SW: Benign tumors of peripheral nerves; in Enzinger FM, Weiss SW (eds): Soft Tissue Tumors. 3rd ed. Mosby, St. Louis, 1995, pp 821-842.

4 Regan JF, Juler GL, Schmutzer KJ: Retroperitoneal neurilemoma. Am J Surg 1977;134:140-145.

5 Felix EL, Wood DK, Das Gupta TK: Tumors of the retroperitoneum. Curr Probl Cancer 1981;6:1-47.

-6 Kim SH, Choi BI, Han MC, et al: Retroperitoneal neurilemoma: CT and MR findings. AJR Am J Roentgenol 1992;159:1023-1026.

7 Neifer R, Nguyen GK: Aspiration cytology of solitary schwannoma. Acta Cytol 1985;29:12-14.

8 Claes H, Oyen R, Stessens R, et al: Solitary benign schwannoma in the psoas muscle. J Urol 1987;137:753-756.

-9 Giglio M, Giasotto V, Medica M, et al: Retroperitoneal ancient schwannoma: case report and analysis of clinico-radiological findings. Ann Urol 2002;36:104-106.

10 Miller PL, Tessler A, Alexander S, et al: Retroperitoneal neurilemmoma. Urology 1978;11:619-623. 